\title{
Factors associated with extrajudicial arrest for syringe possession: results of a department-wide survey of municipal police in Tijuana, Mexico
}

Mario Morales ${ }^{1}$, Claudia Rafful ${ }^{1,2}$, Tommi L. Gaines ${ }^{1}$, Javier A. Cepeda ${ }^{1}$, Daniela Abramovitz ${ }^{1}$, Irina Artamonova ${ }^{1}$, Pieter Baker ${ }^{1}$, Erika Clairgue ${ }^{1}$, Maria Luisa Mittal ${ }^{1,3}$, Teresita Rocha-Jimenez ${ }^{1,4}$, Jaime Arredondo ${ }^{1,4}$, Thomas Kerr ${ }^{5}$, Arnulfo Bañuelos ${ }^{6}$, Steffanie A. Strathdee ${ }^{1}$ and Leo Beletsky ${ }^{1,7^{*}}$

\begin{abstract}
Background: Mexican law permits syringe purchase and possession without prescription. Nonetheless, people who inject drugs (PWID) frequently report arrest for syringe possession. Extrajudicial arrests not only violate human rights, but also significantly increase the risk of blood-borne infection transmission and other health harms among PWID and police personnel. To better understand how police practices contribute to the PWID risk environment, prior research has primarily examined drug user perspectives and experiences. This study focuses on municipal police officers (MPOs) in Tijuana, Mexico to identify factors associated with self-reported arrests for syringe possession.

Methods: Participants were active police officers aged $\geq 18$ years, who completed a self-administered questionnaire on knowledge, attitudes and behaviors related to occupational safety, drug laws, and harm reduction strategies. Univariable and multivariable logistic regression was used to identify correlates of recent syringe possession arrest.

Results: Among $1044 \mathrm{MPOs}$, nearly half (47.9\%) reported always/sometimes making arrests for syringe possession (previous $6 \mathrm{mo}$ ). Factors independently associated with more frequent arrest included being male (Adjusted Odds Ratio $[A O R]=1.62 ; 95 \%$ Confidence Interval $[95 \% \mathrm{Cl}]=1.04-2.52$; working in a district along Tijuana River Canal (where PWID congregate) $(\mathrm{AOR}=2.85 ; 95 \% \mathrm{Cl}=2.16-3.77)$; having recently experienced a physical altercation with PWID (AOR = 2.83; 95\% Cl=2.15-3.74); and having recently referred PWID to social and health services ( $A O R=1.97$; $95 \% \mathrm{Cl}=1.48-2.61)$. Conversely, odds were significantly lower among officers reporting knowing that syringe possession is legal $(\mathrm{AOR}=0.61 ; 95 \% \mathrm{Cl}=0.46-0.82)$.

Conclusions: Police and related criminal justice stakeholders (e.g., municipal judges, prosecutors) play a key role in shaping PWID risk environment. Findings highlight the urgent need for structural interventions to reduce extra-judicial syringe possession arrests. Police training, increasing gender and other forms of diversity, and policy reforms at various governmental and institutional levels are necessary to reduce police occupational risks, improve knowledge of drug laws, and facilitate harm reduction strategies that promote human rights and community health.
\end{abstract}

Keywords: Persons who inject drug, Drug policy, Justice, Human rights, Police, Arrests, Syringe possession

\footnotetext{
* Correspondence: Ibeletsky@ucsd.edu

'Division of Infectious Diseases and Global Public Health, School of Medicine,

University of California San Diego, 9500 Gilman Dr., La Jolla, San Diego,

California 92093, USA

${ }^{7}$ Health in Justice Action Lab, School of Law and Bouvé College of Health

Sciences, Northeastern University, Boston 02115, USA

Full list of author information is available at the end of the article
}

(c) The Author(s). 2018 Open Access This article is distributed under the terms of the Creative Commons Attribution 4.0 International License (http://creativecommons.org/licenses/by/4.0/), which permits unrestricted use, distribution, and reproduction in any medium, provided you give appropriate credit to the original author(s) and the source, provide a link to the Creative Commons license, and indicate if changes were made. The Creative Commons Public Domain Dedication waiver (http://creativecommons.org/publicdomain/zero/1.0/) applies to the data made available in this article, unless otherwise stated. 


\section{Background}

Restrictive laws and aggressive police enforcement of drug and syringe possession are pervasive risk factors for HIV and other blood-borne infections among people who inject drugs (PWID) [1-20]. Worldwide, law enforcement has negatively impacted PWID willingness to purchase and carry sterile syringes, avoidance of sharing syringes and shooting galleries, and utilization of syringe exchange programs [21-35]. Police confiscation of both used and unused syringes negatively influences the way PWID consume drugs [4, 8, 10, 13-17, 23, 36-48]. In addition to the negative health outcomes of incarceration in terms of infectious disease transmission, overdose, and structural vulnerability risk $[49,50]$, arrests for syringe possession constitute a human rights and global health concern that may cause immediate and downstream harm to PWID.

Police encounters with PWID involving syringes may also have a negative health impact on police officers [5, 6, 36, 51-57]. In 1996, among 803 participants in the San Diego Police Department, 29.7\% had at least one needle stick injury (NSI) ever, of which $27.7 \%$ had had two or more; only $39.2 \%$ sought medical attention for the NSI [51]. In Baltimore, between 2010 and 2012, 8\% of police officers reported lifetime prevalence of NSI [36] and 4\% among officers in North Carolina between 2010 and 2012 [55]. Municipal police officers (MPOs) in Tijuana, Mexico, reported a higher prevalence of NSI in 2014 (14.3\%) [56]. High rates of NSI put Tijuana MPOs at an elevated risk of blood-borne infections such as HIV, HCV and HBV. The potential for HCV transmission is especially high due to the elevated antibody seroprevalence (96\%) among PWID in Tijuana [58].

Police knowledge, attitudes, and behaviors towards PWID are potentially modifiable factors that are related to arrest for syringe possession. Previous research suggests these factors vary and may often be detrimental and antithetical to human rights [2, 5, 6, 36, 38, 59-61]. Police officers in Togliatti (Russia) and Tijuana stopped and frisked PWID because they considered them potential crime suspects $[2,62]$. In Rhode Island, police officers (U.S.) were misinformed about the syringe possession law, and those who knew that it was legal to carry syringes continued to treat syringes as contraband [5]. Before receipt of a training on occupational safety, legal knowledge, and harm reduction strategies, half of Rhode Island's police officers who were trained reported that syringe access increased drug use (51\%) and police NSI (58\%) [6]. However, Kyrgyz police officers who received a similar (though more lengthy) training as in Rhode Island, were significantly more likely to have improved their occupational safety knowledge, syringe confiscation avoidance, and supporting referrals to harm reduction organizations [60].
Laws allowing syringe possession or acquisition without a prescription are a noted structural intervention to improve community health. However, extrajudicial syringe possession arrests continue even in context of syringe legality. Police knowledge of the law may be a key factor shaping syringe possession arrests. In Mexico, the level of legal knowledge on syringe possession is low among police and among PWID. Previously, we found that only approximately half (56\%) of MPOs in Tijuana correctly reported that suspects can possess unlimited numbers of syringes under the law of Baja California [61] and 49\% of MPOs reported always/sometimes confiscating syringes in the last 6 months [47]. The discrepancy between black letter law and its understanding was even more pronounced among PWID, where $86 \%$ of the participants reported incorrect knowledge of the syringe possession law [38].

In Tijuana, Mexico, the gap between syringes' formal legal standing and their status under the law on the streets has dire public health implications. HIV prevalence there is triple the national average ( $0.9 \%$ vs. $0.3 \%)$ [44], and transmission remains concentrated among high risk populations [63]. Syringe confiscations among PWID are concentrated in the Centro district [47] and along the Tijuana River Canal, an open-air water artery where PWID congregate and consume drugs [37]. Reports of syringe confiscations in the city have been independently associated with PWID risk behaviors such as receptive syringe sharing [16], seeking assistance to inject [17], using high-dead space syringes (which are more likely to transmit blood-borne infections) [64], injecting in shooting galleries [23], and a higher overall prevalence of HIV infection [39, 65].

Despite the critical role of these encounters in shaping health risk, no previous research (to our knowledge) has elucidated factors associated with syringe possession arrests from the perspective of police officers rather than PWID. In general, police officers have poor knowledge of occupational safety related to NSI, syringe possession laws and harm reduction strategies, and also often hold negative attitudes towards PWID, decriminalization and syringe access initiatives $[5,6,60]$. To better understand what drives these detrimental practices, we aimed to identify factors associated with self-reported syringe possession arrests in a large sample of MPOs. We hypothesized that negative experiences with PWID, not referring PWID to social and health services, and inadequate knowledge of the syringe possession law in Mexico would be positively and significantly associated with arrests for syringe possession.

\section{Methods}

This analysis was undertaken as part of the Escudo (Shield) project, described in detail elsewhere $[56,61,66]$. 
From February 2015 to May 2016, 85\% of the municipal police force in Tijuana (over 1800 participants) was trained on: [1] occupational safety related to interactions with PWID and blood-borne infections, [2] Mexican drug laws, and [3] harm reduction strategies. Inclusion criteria were: $\geq 18$ years of age, being an active MPO, and willing and able to provide consent. To focus on participants who would be expected to interact with PWID and engage in drug law enforcement, we excluded top police officials and officers engaged in administrative, or other nonstreet enforcement duties. Baseline surveys were selfadministered prior to the Escudo training and data were collected on participants' knowledge, attitudes and behaviors towards the three training topics. The study protocol was approved by the Human Research Protections Program of the University of California, San Diego, and by the Institutional Review Board at Universidad Xochicalco, Tijuana.

\section{Measures}

The outcome, syringe possession arrests, was measured by the item: "In the last 6 months, how often have you arrested someone for syringe possession?". This variable was self-reported and measured on a 5-point Likert scale: "always," "sometimes," "rarely," "never," and "do not know." The outcome was dichotomized to always/ sometimes, and never/rarely in order to distinguish the frequency of arrests.

Independent variables included sociodemographic characteristics (i.e., sex, age, education, and marital status), policing characteristics (i.e., years in law enforcement, ever been stuck with a needle, and district of service), attitudes towards drug users (i.e., PWID do not care about health, addiction is a disease, and PWID do not deserve to be treated as other people), interactions with PWID (i.e., recent referral of PWID to social and health services and recent physical altercation), and knowledge of the syringe possession law in Baja California.

We generated an ordinal variable to differentiate the number of times that an MPO had ever been stuck with a needle on duty: 0,1 and 2 or more. The current district of service variable describes the physical location where MPOs were commissioned at the time of the survey. This binary variable differentiates police districts according to their proximity to the Tijuana River Canal: along the Canal (Centro, La Mesa and Mesa de Otay districts) or elsewhere (all other eight districts).

Attitudes towards drug use included three items: "People addicted to drugs do not care about their health," "Drug addiction is a disease," and "Drug users do not deserve to be treated as other people." The first two variables were measured on a 4-point Likert scale (agree, neither agree nor disagree, disagree and do not know). The last variable was measured on a 6-point
Likert scale (strongly agree, agree, neither agree nor disagree, disagree, strongly disagree and do not know) and was trichotomized to strongly agree/agree, neither agree nor disagree, and strongly disagree/disagree.

Interactions with PWID were measured by the items: "In the last 6 months, how many times have you referred drug users to social or health programs?", and "In the last 6 months, how often have you had a physical altercation with a drug user suspect?". Both variables were measured on a 5-point Likert scale (always, sometimes, rarely, never and do not know) and were dichotomized for the analysis: always/sometimes and never/rarely.

Knowledge of the law of syringe possession indicated whether an MPO was aware that syringe possession is legal in Baja California. It was measured by posing the following statement: "Please circle the selection that accurately describes what a suspect can currently possess under the law of Baja California" (none, 2, 5, 15, as many [syringes] as they want, or do not know). Knowledge was dichotomized to "yes" (if the police officers reported that it is legal to carry at least one syringe), and "no" (if they reported that it is illegal to carry any syringe).

\section{Statistical analysis}

The analysis used data from the baseline assessment. Those who reported arresting always/sometimes for syringe possession in the last 6 months (arrestors) were compared to those who reported never/rarely conducting such arrests (non-arrestors) with respect to selected sociodemographic, knowledge and behavioral characteristics by calculating descriptive statistics. Chi-square and Mann-Whitney tests were used for the comparisons that involved categorical and continuous variables, respectively. Univariable and multivariable logistic regression analyses were conducted to identify characteristics associated with syringe possession arrests. The multivariable logistic regression model was built by entering significant $(p<0.10)$ variables from the univariable analyses using a forward stepwise procedure. The log likelihood test statistic was used to assess model fit and to compare nested models. Potential confounders were considered for inclusion in the multivariable model. Multicollinearity was assessed and ruled out upon obtaining appropriate values for the variance inflation factors and largest condition indices.

\section{Results}

A total of 1751 participants were enrolled and completed the Escudo baseline data collection, but 707 MPOs were excluded because they were either higher rank officers, assigned to non-patrol duties, or in service in more than one district. In the resulting sample $(N=$ 1044; Table 1), median age was 37 and median years 
Table 1 Descriptive statistics of municipal police officers by arrest for syringe possession in last 6 months $(N=1044)^{a}$

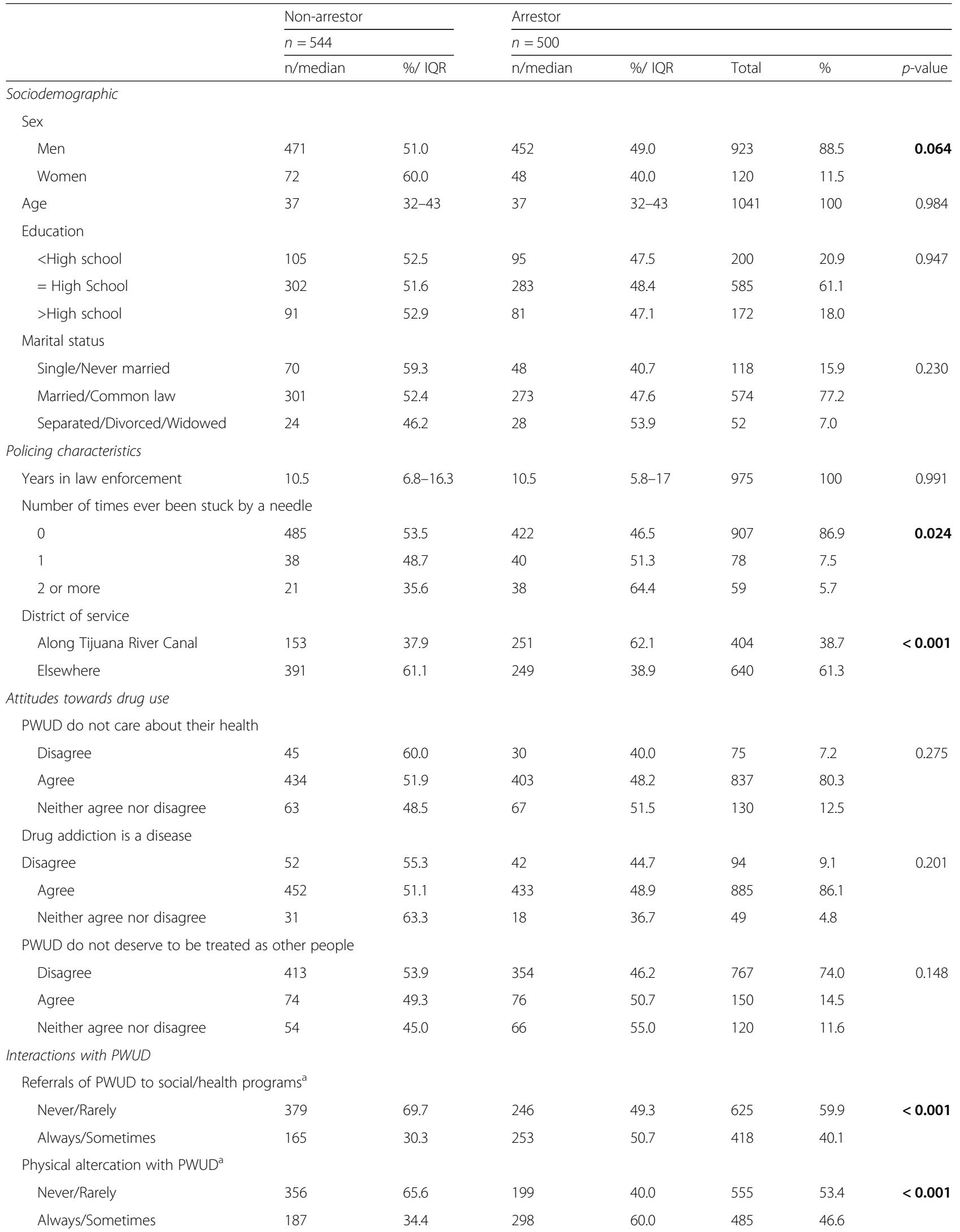


Table 1 Descriptive statistics of municipal police officers by arrest for syringe possession in last 6 months $(N=1044)^{a}($ Continued)

\begin{tabular}{|c|c|c|c|c|c|c|c|}
\hline & \multicolumn{2}{|c|}{ Non-arrestor } & \multicolumn{5}{|l|}{ Arrestor } \\
\hline & \multicolumn{2}{|l|}{$n=544$} & \multicolumn{5}{|l|}{$n=500$} \\
\hline & $\mathrm{n} /$ median & $\% / I Q R$ & $\mathrm{n} /$ median & $\% / I Q R$ & Total & $\%$ & $p$-value \\
\hline \multicolumn{8}{|c|}{ Knowledge of the law of syringe possession } \\
\hline \multicolumn{8}{|c|}{ Can a person possess syringes under the law of Baja California, Mexico? } \\
\hline No & 156 & 29.7 & 180 & 37.9 & 336 & 33.6 & \multirow[t]{2}{*}{0.006} \\
\hline Yes & 369 & 70.3 & 295 & 62.1 & 664 & 66.4 & \\
\hline
\end{tabular}

IQR Interquartile range, PWUD people who use drugs, ${ }^{a}$ the question refers to the last 6 months, $p<0.05$ are bolded

Table 1 and Table 2 refer to PWUD, rather than PWID to accurately reflect the Escudo survey as it asks MPOs about attitudes towards PWUD and interactions with PWUD, rather than attitudes towards PWID or interactions with PWID

working in law enforcement agencies was 10.5 across groups. Most participants were male (88.5\%), married (77.2\%) and had at least a high school education (79.1\%). Finally, almost half of the participants $(47.9 \%)$ reported always/sometimes arresting people for syringe possession in the last 6 months.

Relative to the non-arrestors, the arrestor group exhibited a significantly-higher proportion of MPOs who always/sometimes had recent physical altercations with PWID $(60 \%$ vs. $34.4 \%, p<0.001)$, as well as a significantly-higher proportion of recent arrests for syringe possession along the Tijuana River Canal (Centro, La Mesa and Mesa de Otay districts) (62.1\% vs. 37.9\%, $p<0.001)$. Compared to the non-arrestors, the arrestor group was also more likely to always/sometimes refer PWID to services $(50.7 \%$ vs. $30.3 \%, p<0.001)$ and had a higher proportion of MPOs who have been stuck by a needle two or more times $(64.4 \%$ vs. $35.6 \%, p=0.024)$. Conversely, the non-arrestor groups had a higher proportion of MPOs with the correct understanding of the syringe possession law as compared to the arrestor group $(70.3 \%$ vs. $62.1 \%, p=0.006)$. A marginally-higher proportion of non-arrestors were female relative to the arrestors $(60 \%$ vs. $40 \%, p=0.064)$. Finally, no significant differences were found between the arrestors and non-arrestors with regards to attitudes towards drug use and users.

Table 2 presents the results of the univariable and multivariable logistic regression models. According to the multivariable analysis, MPOs working along the Tijuana River Canal were 2.85 (95\% Confidence Interval $[C I]=2.16-3.77)$ times more likely to always/sometimes arrest somebody for syringe possession, when compared to MPOs working elsewhere. The odds of always/sometimes arresting someone for syringe possession of MPOs who reported a recent physical altercation with PWID were $2.83(\mathrm{CI}=2.15-3.74)$ times the corresponding odds of MPOs who did not face such altercation. Additionally, the odds of always/sometimes arresting someone for carrying a syringe were $1.97(\mathrm{CI}=1.48-2.61)$ times higher among MPOs who referred PWID to social and health programs as compared to those who did not. Male
MPOs were $1.62(\mathrm{CI}=1.04-2.52)$ times more likely to always/sometimes arrest somebody for syringe possession, as compared to a female MPOs. Finally, the odds of always/sometimes arresting someone for carrying a syringe among MPOs who knew syringe possession is legal in Baja California were $0.61(\mathrm{CI}=0.46-0.82)$ times the corresponding odds of MPOs who did not know the syringe possession law. Despite being significant in the univariable logistic regression model, having been stuck with a needle was not significant in the final model, nor did it affect the significance of other variables in the model.

Missing values represented $4.68 \%$ of the total observations in the model and $0.97 \%$ in the overall sample. "Do not know" answers in the outcome and all the covariates were excluded from the analysis because of their low number of cases (outcome $=0.003 \%$, referral $=0.003 \%$, altercation $=0.006 \%$, and syringe possession law $=$ $0.043 \%$ ). The model did not present missing values problem considering that the borderline for the missing value analysis on randomness is 5\% [67].

\section{Discussion}

In this large study of MPOs in Tijuana, nearly half reported arresting PWID for syringe possession in the past 6 months, despite syringes' legal status. This proportion is nearly identical to that reported in a study of PWID in Tijuana 10 years earlier [16]. These findings echo data from elsewhere suggesting that liberalizing drug and syringe access policy alone are not sufficient to reduce harm to PWID flowing from policing practices [68]. While knowledge of the syringe law was associated with a lower frequency of arrest for syringe possession, factors like experiences of physical altercation with PWID, having referred PWID to social or health services, patrolling high-intensity drug areas, and being male are also predictive of more frequent syringe possession arrests.

This study's identification of a significant association between knowledge of syringe possession law and arrests for syringe possession is novel. This link between policy knowledge and street practice adds credence to claims 
Table $\mathbf{2}$ Odds of arresting for syringe possession among municipal police officers ( $n=995$ )

\begin{tabular}{|c|c|c|c|c|c|c|c|c|}
\hline \multirow{2}{*}{ Sociodemographic } & \multirow[t]{2}{*}{ OR } & \multicolumn{2}{|c|}{$95 \% \mathrm{Cl}$} & \multirow[t]{2}{*}{$p$-value } & \multirow[t]{2}{*}{ AOR } & \multicolumn{2}{|c|}{$95 \% \mathrm{Cl}$} & \multirow[t]{2}{*}{$p$-value } \\
\hline & & & & & & & & \\
\hline \multicolumn{9}{|l|}{ Sex (Ref: Women) } \\
\hline Men & 1.44 & 0.98 & 2.12 & 0.065 & 1.62 & 1.04 & 2.52 & 0.033 \\
\hline Age & 1.00 & 0.98 & 1.01 & 0.795 & & & & \\
\hline \multicolumn{9}{|l|}{ Education (Ref: <High School) } \\
\hline$=$ High School & 1.04 & 0.75 & 1.43 & 0.831 & & & & \\
\hline$>$ High School & 0.98 & 0.65 & 1.48 & 0.938 & & & & \\
\hline \multicolumn{9}{|l|}{ Marital status (Ref: Single/Never married) } \\
\hline Married/Common law & 1.32 & 0.88 & 1.98 & 0.173 & & & & \\
\hline Separated/Divorced/Widowed & 1.70 & 0.88 & 3.28 & 0.113 & & & & \\
\hline \multicolumn{9}{|l|}{ Policing characteristic } \\
\hline Years in law enforcement & 1.00 & 0.98 & 1.01 & 0.806 & & & & \\
\hline \multicolumn{9}{|l|}{ Number of times ever been stuck by a needle } \\
\hline 1 (Ref: 0) & 1.21 & 0.76 & 1.92 & 0.420 & & & & \\
\hline 2 or more & 2.08 & 1.20 & 3.60 & 0.009 & & & & \\
\hline \multicolumn{9}{|l|}{ District of service (Ref: Elsewhere) } \\
\hline Along Tijuana River Canal & 2.58 & 1.99 & 3.33 & $<0.001$ & 2.85 & 2.16 & 3.77 & $<0.001$ \\
\hline \multicolumn{9}{|l|}{ Attitudes towards drug use } \\
\hline \multicolumn{9}{|l|}{ PWUD do not care about their health } \\
\hline Agree (Ref: Disagree) & 1.39 & 0.86 & 2.25 & 0.177 & & & & \\
\hline Neither agree nor disagree & 1.60 & 0.90 & 2.84 & 0.112 & & & & \\
\hline \multicolumn{9}{|l|}{ Drug addiction is a disease } \\
\hline Agree (Ref: Disagree) & 1.19 & 0.77 & 1.82 & 0.434 & & & & \\
\hline Neither agree nor disagree & 0.72 & 0.35 & 1.46 & 0.362 & & & & \\
\hline \multicolumn{9}{|c|}{ PWUD do not deserve to be treated as other people } \\
\hline Agree (Ref: Disagree) & 1.20 & 0.84 & 1.70 & 0.311 & & & & \\
\hline Neither agree nor disagree & 1.43 & 0.97 & 2.10 & 0.072 & & & & \\
\hline \multicolumn{9}{|l|}{ Interactions with PWUD } \\
\hline \multicolumn{9}{|l|}{ Referrals of PWUD to social/health programs ${ }^{a}$} \\
\hline All the time/Sometimes (Ref: Never/Rarely) & 2.36 & 1.83 & 3.04 & $<0.001$ & 1.97 & 1.48 & 2.61 & $<0.001$ \\
\hline \multicolumn{9}{|l|}{ Physical altercation with PWUD ${ }^{a}$} \\
\hline All the time/Sometimes (Ref: Never/Rarely) & 2.85 & 2.22 & 3.67 & $<0.001$ & 2.83 & 2.14 & 3.74 & $<0.001$ \\
\hline \multicolumn{9}{|l|}{ Knowledge of the law of syringe possession } \\
\hline \multicolumn{9}{|c|}{ Can a person possess syringes under the law of Baja California, Mexico? (Ref: No) } \\
\hline Yes & 0.69 & 0.53 & 0.90 & 0.006 & 0.61 & 0.46 & 0.82 & $<0.001$ \\
\hline
\end{tabular}

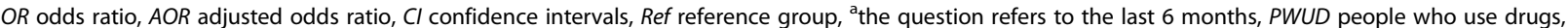
Significant variables at $p<0.05$ are bolded

that formal law reform, when operationalized through education programs, may be an effective structural intervention to address officer safety and community health [69]. This finding is particularly relevant considering a previous analysis comparing pre- and post-training surveys with this cohort of MPOs that found significant improvement $(p<$ 0.001 ) in their conceptual knowledge of syringe possession law (from 67 to 96\%), defined as the recognition that it is legal to carry one or more syringes [61].

We also found that female MPOs were significantly less likely to report syringe possession arrests compared to male MPOs. Policing is a male-dominated profession and women have been underrepresented in its ranks [70]. This study highlights the role of female MPOs as 
vital to reducing occupational risks and promoting harm reduction practices among police [47]. Previous research suggests female police officers possess greater empathy and communication skills, and are less likely to engage in aggressive behavior, such as threats, use of force incidents, and extra-judicial search and arrest [71-73]. Interventions that capitalize upon the positive role of female MPOs could have a multiplier effect by improving relations with people who use drugs and the broader community, while advancing officer occupational safety and morale. Beyond individual-level behavior, female MPOs may exert positive peer pressure or other normative influence on policing ecosystems in ways that suppress overall arrests for syringe possession.

Neighborhoods with high drug using activity have previously been identified as key locations for MPOs encounters with PWID [14, 37, 45]. Our findings are consistent with previous analyses of MPOs that identified a positive association between being stationed in Centro, La Mesa and Mesa de Otay districts (high drug use districts along the Tijuana River Canal) and syringe confiscation [37, 45, 47]. In the face of police abuse and harassment reports by PWID [4, 8, 10, 15, 41, 43], police training on harm reduction strategies and enhanced monitoring of arrests for syringe possession are especially important in high drug use neighborhoods.

Unexpectedly, MPOs who reported more frequent referrals of PWID to social and health services during last 6 months were more likely to arrest for syringe possession in the same period of time; it is not clear whether these actions occurred within the context of the same encounter, however. It is possible that these referrals were made to compulsory treatment facilities as a punishment for aberrant behavior that did not qualify as a violation of criminal law [3], or were part of a zero-tolerance approach advanced by the Tijuana's Ministry of Public Safety [45]. Between December 2014 and March 2015, a policing program known as Tijuana Mejora implemented along the Tijuana River Canal resulted in the displacement of 800 to 1000 people, the majority of whom were involuntary transported to "treatment" centers [74]. Future research should assess what MPOs understand as a referral and whether it is characterized as voluntary or compulsory.

MPOs often present PWID in front of a municipal judge after arresting them for syringe possession [62]. In these instances, municipal judges-not the officershave the authority to dismiss the arrest and/or divert PWID to social and health services. Thus, future interventions should recognize the critical role of municipal judges and other interactors within the criminal justice system above and beyond MPOs. Regardless of how referrals occur, there are limited services specialized for PWID in Tijuana [75]. Many existing substance use treatment facilities offer only abstinence-based modalities that are not evidence-based and may, in fact, be causing more harm than good [75]. In other settings, police referrals to places like substance use treatment providers or safe injection facilities can be a source of benefit for PWID and an opportunity to align public health and security efforts [76]. It is important to understand the current nature of these referrals and work to improve them, concurrently addressing the quality, acceptability, and affordability of substance use resources available in Tijuana, elsewhere in Mexico, and beyond.

This study has several limitations. As a cross-sectional analysis, we cannot infer causal relationships. Qualitative research may assist in elucidating the temporality of these associations, in addition to future analyses from Escudo that will assess these associations longitudinally. As this analysis is based on self-reported data while officers were on duty for mandated occupational training, we cannot assume unbiased reporting. Bias may have been minimized since surveys did not include identifying information and were collected by study staff who were not employed by the police department or the police academy. Additionally, precision of our outcome may be a concern since it was not clear how the four answer options of our dependent variable were understood by the participants because it conflated exposure and frequency. For example, an MPO who stops 40 people and arrests 10 is not differentiated from the MPO who stops 10 people and arrest them all. There may also be differential understanding by the MPOs as to what constitutes a referral (voluntary or compulsory) and what constitutes a physical altercation. Further qualitative research needs to define those differences. In this analysis, we cannot determine the impact of peer pressure on arrests for syringe possession. Finally, considering that policing is not a lone activity, there is a need to further explore this topic in subsequent qualitative research. For instance, MPOs may feel pressure from superiors or peers to meet arrest or other encounter quotas.

Overall, in order to reduce harm to PWID and improve occupational safety among police officers, drug and syringe access policy reform should be coupled with police education programs, police oversight mechanisms and structures, effective referral processes, and scale-up in evidence-based drug treatment resources. High drug use neighborhoods should receive particular attention and the critical role of female police officers should be recognized. Future research and interventions are required to maximize MPOs' knowledge (on occupational safety, drug laws and harm reduction), improve policing tactics and reduce harm in the context of drug and syringe access policy reform. Efforts are also needed to include training of municipal judges, who are responsible for referring PWID to social and health services. 


\section{Conclusions}

Our study highlights the need for structural interventions targeting MPOs and related key stakeholders, such as municipal judges and prosecutors. Knowledge of the syringe possession law is associated with reduced arrests for carrying syringes, but altercations with PWID, referrals to services, patrolling hot spots and being male increases the odds of those arrests. Thus, police training, personnel diversification, and policy reforms at various governmental and institutional levels are necessary to reduce police occupational risks, improve knowledge of drug laws, and facilitate harm reduction strategies that promote human rights and community health.

\footnotetext{
Abbreviations

HBV: Hepatitis B virus; HCV: Hepatitis C virus; HIV: Human immunodeficiency virus; MPO: Municipal police officer; NSI: Needlestick injury; PWID: People who inject drugs
}

\section{Acknowledgements}

The authors also acknowledge assistance from the Ministry of Public Safety in Tijuana and its Police Academy.

\section{Funding}

Support for the Escudo project was provided through grants from the Open Society Foundations Latin America Program grant OR2013-11352 and OR2014-18327, UCSD Center for AIDS Research International Pilot Grant NIAID 5P30AI036214, and the National Institute on Drug Abuse (NIDA; R01DA039073 and R37DA019829). The Fogarty International Center of the National Institutes of Health under award Number D43TW008633 supported MLM, TR, CR and JA. NIDA supported MLM and JAC through T32DA023356 and K01DA043421. UC-MEXUS/CONACT scholarship supported TR, CR and JA. UC MEXUS Dissertation Grant DI 15-42, and NIDA R25 DA026401 also supported CR. This publication resulted in part from research supported by the University of California, San Diego, Center for AIDS Research (CFAR), an $\mathrm{NIH}$-funded program (P30 Al036214), which is supported by the following $\mathrm{NIH}$ Institutes and Centers: NIAID, NCI, NIMH, NIDA, NICHD, NHLBI, NIA, NIGMS, and NIDDK. The above-mentioned funding sources had no involvement in the study design, collection, analysis, and interpretation of data; in the writing of the report; or in the decision to submit the manuscript for publication.

\section{Availability of data and materials}

The datasets used and/or analyzed during the current study are available from the corresponding author upon reasonable request.

\section{Authors' contributions}

$L B, S A S$ designed and conceived of the study. MM, DA and IA undertook the analysis. $L B, P B, C R$, TLG, JAC, EC, MLM, TRJ, JA, TK and AB contributed to data interpretation. MM drafted the manuscript and all authors reviewed and edited drafts of the manuscript. All authors read and approved the final manuscript.

\section{Ethics approval and consent to participate}

The study protocol and consent documentation was approved by the Human Research Protections Program of the University of California, San Diego, and by the Institutional Review Board at Universidad Xochicalco, Tijuana.

\section{Consent for publication}

Not applicable.

\section{Competing interests}

The authors declare that they have no competing interests.

\section{Publisher's Note}

Springer Nature remains neutral with regard to jurisdictional claims in published maps and institutional affiliations.

\section{Author details}

'Division of Infectious Diseases and Global Public Health, School of Medicine, University of California San Diego, 9500 Gilman Dr., La Jolla, San Diego, California 92093, USA. ${ }^{2}$ Centre for Urban Health Solutions, St. Michael's Hospital, Toronto, Canada. ${ }^{3}$ School of Medicine, Universidad Xochicalco, 4850 Calle Rampa Yumalinda, Chapultepec Alamar, 22110 Tijuana, Baja California, Mexico. ${ }^{4}$ School of Public Health, San Diego State University, 5500 Campanile Dr, San Diego, California 92182, USA. ${ }^{5}$ Center of Excellence in HIV/AIDS, University of British Columbia, 2206 East Mall, Vancouver, BC V6T 1Z3, Canada. ${ }^{6}$ Department of Planning and Special Projects, Secretaría de Seguridad Pública Municipal, 2141 Blvd Cuauhtémoc Sur y Río Suchiate, 22015 Tijuana, Mexico. ${ }^{7}$ Health in Justice Action Lab, School of Law and Bouvé College of Health Sciences, Northeastern University, Boston 02115, USA.

Received: 19 April 2018 Accepted: 29 August 2018

Published online: 15 September 2018

\section{References}

1. Rhodes T. The 'risk environment': a framework for understanding and reducing drug-related harm. Int J Drug Policy. 2002;13:85-94.

2. Rhodes T, Platt L, Sarang A, Vlasov A, Mikhailova L, Monaghan G. Street policing, injecting drug use and harm reduction in a Russian city: a qualitative study of police perspectives. J Urban Health. 2006:83(5):911-25.

3. Sarang A, Rhodes T, Sheon N, Page K. Policing drug users in Russia: risk, fear, and structural violence. Subst Use Misuse. 2010;45:813-64.

4. Strathdee S, Lozada R, Pollini RA, Brouwer KC, Mantsios A, Abramovitz DA, et al. Individual, social, and environmental influences associated with HIV infection among injection drug users in Tijuana, Mexico. J Acquir Immune Defic Syndr. 2008;47(3):369-76.

5. Beletsky L, Macalino GE, Burris S. Attitudes of police officers towards syringe access, occupational needle-sticks, and drug use: a qualitative study of one city police department in the United States. Int J Drug Policy. 2005:16:267-74.

6. Beletsky L, Agrawal A, Moreau B, Kumar P, Weiss-Laxer N, Heimer R. Police training to align law enforcement and HIV prevention: preliminary evidence from the field. Am J Public Health. 2011;101(11):2012-5.

7. Beletsky L, Bhatti U, Closic C, Graff J, Fennell DN. Harmonizing harm reduction and law enforcement: strategies for prevention, monitoring, and response. 2008.

8. Beletsky L, Martinez G, Gaines T, Nguyen L, Lozada R, Rangel G, et al. Mexico's northern border conflict: collateral damage to health and human rights of vulnerable groups. Rev Panam Salud Publica. 2012;31(5):403-10.

9. Beletsky L, Thomas R, Smelyanskaya M, Artamonova I, Shumskaya N, Dooronbekova A, et al. Policy reform to shift the health and human rights environment for vulnerable groups: the case of Kyrgyztan's instruction 417. Health Hum Rights. 2012;14(2):34-48

10. Beletsky L, Lozada R, Gaines T, Abramovitz D, Staines H, Vera A, Rangel G, Arredondo J, Strathdee SA. Syringe confiscation as an HIV risk factor: the public health implications of arbitrary policing in Tijuana and Ciudad Juarez, Mexico. J Urban Health. 2013:90(2):284-98.

11. Beletsky L, Heller D, Jenness SM, Neaigus A, Gelpi-Acosta C, Haga H. Syringe access, syringe sharing, and police encounters among people who inject drugs in new York City: a community-level perspective. Int J Drug Policy. 2014:25(1):105-11.

12. Davis CS, Beletsky L. Bundling occupational safety with harm reduction information as a feasible method for improving police receptiveness to syringe access programs: evidence from three U.S. cities. Harm Reduction J. 2009;6:16.

13. Werb D, Wagner KD, Beletsky L, Gonzalez-Zuniga P, Rangel G, Strathdee SA. Police bribery and access to methadone maintenance therapy within the context of drug policy reform in Tijuana, Mexico. Drug Alcohol Depend. 2015;148:221-5

14. Werb D, Strathdee SA, Vera A, Arredondo J, Beletsky L, Gonzalez-Zuniga P, et al. Spatial patterns of arrests, police assault and addiction treatment center locations in Tijuana, Mexico. Addiction. 2016;111:1246-56.

15. Pinedo M, Burgos JL, Zuniga ML, Perez R, Macera CA, Ojeda VD. Police victimization among persons who inject drugs along the US-Mexico border. J Stud Alcohol Drugs. 2015;76(5):758-63.

16. Pollini RA, Brouwer KC, Lozada R, Ramos R, Cruz MF, Magis-Rodriguez C, et al. Syringe possession arrests are associated with receptive syringe sharing in two Mexico-US border cities. Addiction. 2007;103:101-8. 
17. Robertson AM, Vera A, Gallardo M, Pollini RA, Patterson TL, Case P, et al. Correlates of seeking injection assistance among injection drug users in Tijuana, Mexico. Am J Addict. 2010;19(4):357-63.

18. Ahmed T, Long TN, Huong PT, Steward DE. Drug injecting and HIV risk among injecting drug users in Hai Phong, Vietnam: a qualitative analysis. BioMed Central Public Health. 2015;15(32):13.

19. Case P, Meehan T, Jones TS. Arrests and incarceration of injection drug users for syringe possession in Massachusetts: implications for HIV prevention. J Acquir Immune Defic Syndr Hum Retrovirol. 1998;18(1):S71-75.

20. Global Commission on Drug Policy. Taking Control: Pathways to Drug Policies that Work. Geneva: Global Commission on Drug Policy; 2014. p 25

21. Hammett TM, Bartlett NA, Chen Y, Ngu D, Cuong DD, Phuong NM, et al. Law enforcement incluences on HIV prevention for injection drug users: observations from a cross-border project in China and Vietnam. Int J Drug Policy. 2005;16:235-45

22. Bluthenthal RN, Lorvick J, Kral AH, Erringer EA, Kahn JG. Collateral damage in the war on drugs: HIV risk behaviors among injection drug users. Int J Drug Policy. 1999;10:25-38.

23. Philbin M, Pollini RA, Ramos R, Lozada R, Brouwer KC, Ramos ME, et al. Shooting gallery attendance among IDUs in Tijuana and ciudad Juarez, Mexico: correlates, prevention opportunities, and the role of the environment. AIDS Behav. 2008;12:552-60.

24. Strathdee SA, Beletsky L, Kerr T. HIV, drugs and the legal environment. Int J Drug Policy. 2015;26:S27-32.

25. Rhodes T, Mikhailova L, Sarang A, Lowndes CM, Rylkov A, Khutorskoy M, et al. Situational factors influencing drug injecting, risk reduction and syringe exchange in Togliatti City, Russian Federation: a qualitative study of micro risk environment. Soc Sci Med. 2003;57(1):39-54.

26. Koester SK. Copping, running, and paraphernalia Laws: contextual variables and needle risk behavior among injection drug users in Denver. Hum Organ. 1994:53(3):287-95

27. Strathdee SA, Zafar T, Brahmbhatt H, Baksh A, ul Hassan S. Rise in needle sharing among injection drug users in Pakistan during the Afghanistan war. Drug Alcohol Depend. 2003;71(1):17-24.

28. Harvey E, Strathdee SA, Patrick DM, Ofner M, Archibald CP, Eades G, et al. A qualitative investigation into an HIV outbreak among injection drug users in Vancouver, British Columbia. AIDS Care. 1998;10(3):313-21.

29. Maher $L$, Dixon D. Policing and public health: law enforcement and harm minimization in a street-level drug market. The Br J Criminol. 1999;39(4): 488-512.

30. Wood E, Kerr T, Small W, Jones J, Schechter MT, Tyndall MW. The impact of a police presence on access to needle exchange programs. J Acquir Immune Defic Syndr. 2003;34(1):116-7.

31. Cooper H, Moore L, Gruskin S, Krieger N. The impact of a police drug crackdown on drug injectors' ability to practice harm reduction: a qualitative study. Soc Sci Med. 2005;61(3):673-84.

32. Burris S, Strathdee SA. To serve and protect? Toward a better relationship between drug control policy and public health. AIDS. 2006;20:117-8.

33. Rich JD, Dickinson BP, Liu KL, Case P, Jesdale B, Ingegneri RM, et al. Strict syringe laws in Rhode Island are associated with high rates of reusing syringes and HIV risks among injection drug users. J Acquir Immune Defic Syndr Hum Retrovirol. 1998;18(1):140-1.

34. Beletsky L, Grau LE, White E, Bowman S, Heimer R. The roles of law, client race and program visibility in shaping police interference with the operation of US syringe exchange programs. Addiction. 2011;106(2):357-65.

35. Burris S, Blankenship KM, Donoghoe M, Sherman S, Vernick JS, Case P, et al. Addressing the "risk environment" for injection drug users: the mysterious case of the missing cop. Milbank Q. 2004;82(1):125-56.

36. Cepeda JA, Beletsky L, Sawyer A, Serio-Chapman C, Smelyanskaya M, Han J, et al. Occupational safety in the age of the opioid crisis: needle stick injury among Baltimore police. J Urban Health. 2017;94(1):100-3.

37. Gaines T, Beletsky L, Arredondo J, Werb D, Rangel G, Vera A, et al. Examining the spatial distribution of law enforcement encounters among people who inject drugs after implementation of Mexico's drug policy reform. J Urban Health. 2014;92(2):338-51.

38. Beletsky L, Wagner KN, Arredondo J, Palinkas L, Magis-Rodriguez C, Strathdee SA. Implementing Mexico's "Narcomenudeo" Drug Law Reform: A Mixed-Methods Assessment of Early Experiences among People Who Inject Drugs. 2016;10(4):384-401.

39. Strathdee $S$, Lozada R, Martinez G, Vera A, Rusch M, Nguyen L, et al. Social and structural factors associated with HIV infection among female sex workers who inject drugs in the Mexico-US border region. PLoS One. 2011;6(4):8.

40. Strathdee S, Davila W, Case P, Firestone M, Brouwer KC, Perez SG, et al. "vivo Para consumirla y la consumo Para vivir" ["I live to inject and inject to live"]: high-risk injection behaviors in Tijuana, Mexico. J Urban Health. 2005;82(3): iv58-73.

41. Miller CL, Firestone M, Ramos R, Burris S, Ramos ME, Case P, et al. Injecting drug Users' experiences of policing practices in two Mexican-U.S. border cities: public health Prespectives. Int J Drug Policy. 2008;19(4):324-31.

42. Pollini RA, Alvelais J, Gallardo M, Vera A, Lozada R, Magis C, et al. The harm inside: injection during incarceration among male injection drug users in Tijuana, Mexico. Drug Alcohol Depend. 2009;103(1-2):52-8.

43. Volkmann T, Lozada R, Anderson CM, Patterson TL, Vera A, Strathdee SA. Factors associated with drug-related harms related to policing in Tijuana. Mex Harm Reduction J. 2011;8(7):1-8

44. Pinedo M, Burgos JL, Ojeda VD. A critical review of social and structural conditions that influence HIV risk among Mexican deportees. Microbes Infect. 2014;16:379-90.

45. Gaines T, Werb D, Arredondo J, Alaniz VM, Vilalta C, Beletsky L. The spatial-temporal pattern of policing following a drug policy reform: triangulating self-reported arrests with official crime statistics. Subst Use Misuse. 2017;52(2):214-22.

46. Wood EF, Werb D, Beletsky L, Rangel G, Cuevas Mota J, Garfein RS, et al. Differential experiences of Mexican policing by people who inject drugs residing in Tijuana and San Diego. Int J Drug Policy. 2017;41:132-9.

47. Cepeda JA, Strathdee SA, Arredondo J, Mittal ML, Rocha T, Morales M, et al. Assessing police officers' attitudes and legal knowledge on behaviors that impact HIV transmission among people who inject drugs. Int J Drug Policy. 2017:50:56-63.

48. Rafful C, Zule W, Gonzalez-Zuniga P, Werb D, Medina-Mora ME, MagisRodriguez C, et al. High dead-space syringe use among people who inject drugs in Tijuana, Mexico. Am J Drug Alcohol Abuse. 2015:41(3):220-5.

49. Kwásniewski A, Jahangir A, Fuentes C, Gaviria G, Zedillo E, Henrique-Cardoso $F$, et al. The war on drugs and HIV/AIDS. How the criminalization of drug use fuels the global pandemic. In: Global Commision on drug policy; 2012.

50. Global Commission on Drug Policy. The negative impact of the war on drugs on public health: the hidden hepatitis C epidemic. Geneva: Global Commission on Drug Policy; 2013. p 24.

51. Lorentz J, Hill L, Samimi B. Occupational Needlestick injuries in a metropolitan police force. Am J Prev Med. 2000;18(2):146-50.

52. Groseclose SL, Weinstein B, Stephen-Jones T, Valleroy LA, Fehrs LJ, Kassler WJ. Impact of increased legal access to needle and syringes on practices of injecting-drug users and police officers-Connecticut, 1992-1993. J Acquir Immune Defic Syndr Hum Retrovirol. 1995;10:82-9.

53. Pagane J, Chanmugam A, Kirsch T, Kelen GD. New York city police officers incidence of transcutaneous exposure. Occup Med. 1996;46(4):285-8.

54. Sonder GJB, Bovée LPMJ, Coutinho RA, Baayen D, Spaargaren J, Van den Hoek A. Occupational exposure to bloodborne viruses in the Amsterdam police force, 2000-2003. Am J Prev Med. 2005;28(2):169-74.

55. Davis CS, Johnston J, de Saxe Zerden L, Clark K, Castillo T, Childs R. Attitudes of North Carolina law enforcement officers towards syringe decriminalization. Drug Alcohol Depend. 2014;144:265-9.

56. Mittal ML, Beletsky L, Patino E, Abramovitz D, Rocha T, Arredondo J, et al. Prevalence and correlates of needle-stick injuries among active duty police officers in Tijuana, Mexico. J Int AIDS Soc. 2016;19(4S3):20874.

57. Flavin J. Police and HIV/AIDS: the risk, the reality, the response. Am J Crim Justice. 1998;23(1):33-58.

58. Ramos R, Ferreira-Pinto JB, Brouwer KC, Ramos ME, Lozada RM, FirestoneCruz $\mathrm{M}$, et al. A tale of two cities: social and environmental influences shaping risk factors and protective behaviorss in two Mexico-US border cities. Health Place. 2009;15(4):999-1005.

59. Beyer L, Crofts N, Reid G. Drug offending and criminal justice responses: practitioners' perspectives. Int J Drug Policy. 2002;13(3):203-11.

60. Beletsky L, Thomas R, Shumskaya N, Artamonova I, Smelyanskaya M. Police education as a component of national HIV response: lessons from Kyrgyzstan. Drug Alcohol Depend. 2013;132(1). https://doi.org/10.1016/j. drugalcdep.2013.06.027

61. Arredondo J, Strathdee SA, Cepeda JA, Abramovitz D, Artamonova I,

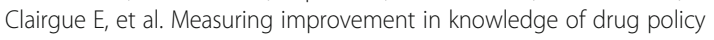
reforms following a police education program in Tijuana, Mexico. Harm Reduction J. 2017;14(72):1-10. 
62. Morales M, Mittal ML, Rocha T, Rafful C, Clairgue E, Arredondo J, et al. Translating drug policy reform: a qualitative study of police officer knowledge, perceptions, and beliefs following a training on Mexico's Narcomenudeo law. ISSDP conference, Aarhus, Denmark. 2017.

63. Strathdee SA, Magis-Rodriguez C, Mays VM, Jimenez R, Patterson TL. The emerging HIV epidemic on the Mexico-US border: an international case study characterizing the role of epidemiology in surveillance and response. Ann Epidemiol. 2012;22(6):426-38.

64. Bobashev GV, Zule WA. Modeling the effect of high dead-space syringes on the human immudeficiency virus (HIV) epidemic among injecting drug users. Addiction. 2010;105:1439-47.

65. Borquez A, Beletsky L, Nosyk B, Strathdee SA, Madrazo A, Abramovitz D, et al. The effect of public health-oriented drug law reform on HIV incidence in people who inject drugs in Tijuana, Mexico: an epidemic modelling study. Lancet Public Health. 2018; https://doi.org/10.1016/S2468-2667/(18)30097-5.

66. Strathdee SA, Arredondo J, Rocha T, Abramovitz D, Rolon ML, Patino E, et al. A police education programme to integrate occupational safety and HIV prevention: protocol for a modified stepped-wedge study design with parallel prospective cohorts to assess behavioural outcomes. BMJ Open. 2015;5:e008958. https://doi.org/10.1136/bmjopen-2015-008958

67. Glantz SA. Primer of biostatistics. 7th ed. ed. New York: McGraw-Hill; 2012.

68. Beyrer C. HIV epidemiology update and transmission factors: risks and risk contexts--16th international AIDS conference epidemiology plenary. Clin Infect Dis. 2007:44(7):981-7.

69. Strathdee SA, Beletsky L. Harmonizing law enforcement and HIV prevention through a police education program La Jolla: UCSD Division of Global Public Health; 2015. [4/9/2015]. Available from: https://gph.ucsd.edu/ research/active-projects/Pages/harmonizing.aspx

70. Fitzsimmons T. A lack of female officers causes police brutality. In: Cothran H, editor. Police brutality: Opposing viewpoints. San Diego, CA.: Greenhaven Press; 2001. p. 75-83.

71. Rabe-Hemp CE. Female officers and the ethic of care: does officer gender impact police behaviors? J Crim Just. 2008;36:426-34

72. Schuck AM, Rabe-Hemp C. Women police: the use of force by and against female officers. Women Crim Just. 2008;16(4):91-117.

73. Prenzler T. Police corruption. Preventing misconduct and maintaining integrity. New York: CRC Press; 2009

74. Duran L, Caballero Y. Limpieza. In: en Bordo dispersa adictos. Frontera; 2015.

75. CONADIC. Directorio de establecimientos especializados en el tratamiento de las adicciones en modalidad residencial reconocidos por la Comisi'on Nacional contra las Adicciones. In: Adicciones CNcl, editor. México 2017.

76. DeBeck K, Wood E, Zhang R, Tyndall M, Montaner J, Kerr T. Police and public health partnerships: evidence from the evaluation of Vancouver's supervised injection facility. Subst Abuse Treat Prev Policy. 2008;3:11.

\section{Ready to submit your research? Choose BMC and benefit from:}

- fast, convenient online submission

- thorough peer review by experienced researchers in your field

- rapid publication on acceptance

- support for research data, including large and complex data types

- gold Open Access which fosters wider collaboration and increased citations

- maximum visibility for your research: over $100 \mathrm{M}$ website views per year

At BMC, research is always in progress.

Learn more biomedcentral.com/submissions 